\section{In memoriam of Prof. Mels van der Ploeg}

It is with deep sadness that we announce that Mels van der Ploeg passed away on the 5th of April 2011.

Mels was born in Rotterdam in 1926, but lived until his secondary school in Indonesia (at that time called Dutch East Indies), during the II World War. Back to the Netherlands, he obtained a BS degree in Chemistry at the University of Amsterdam, and then the MS degree in Organic Chemistry. In 1963, he discussed a PhD thesis on Cytochemistry, entitled "Het Mechanisme van de Peroxydase-DOPA reactie", The Mechanism of the PeroxydaseDOPA reaction.

In the following years, he became senior scientist and assistant professor in the laboratory of Pathology, at the Department of Histochemistry of the University of Leiden, where he joined the research group leaded by Piet van Duijn, with whom he initiated the first pioneering studies on quantitative enzyme histochemistry and cytochemistry using matrix model systems. These first studies were followed by a significant period in which his research was dedicated to the development and application of cytochemical procedures for the identification, localization and, most importantly, quantification of cellular DNA content. These studies culminated in the setting of new techniques for the detection of nucleic acid sequences in microscopic preparations of cell nuclei or metaphase chromosomes. In fact, at the beginning of the 80 's, he started a project on the first development of fluorescence in situ hybridization (FISH) technique, in which the Dutch group acquired international leadership. The outstanding importance of these studies is outlined by the several applications in fundamental bio-medical research areas, including cytogenetics, oncology, and virus diagnosis.

Mels was a member of several scientific Societies, including the most important ones in the field of histochemistry and cytochemistry, and analytical cytometry, in which he served both as Secretary and as President. He was also a member of the Editorial Board of leading journals in the field, among which Histochemistry, Histochemical Journal, Cytometry, European Journal of Histochemistry, Analytical Cytometry.

His scientific merits, especially in the field of nuclear cytochemistry, led him to be assigned several honours, including the first Maffo Vialli Award for Histochemistry, in 1999, by the Italian Society of Histochemistry.

We will miss a colleague from whom we learned the very first steps of automation in

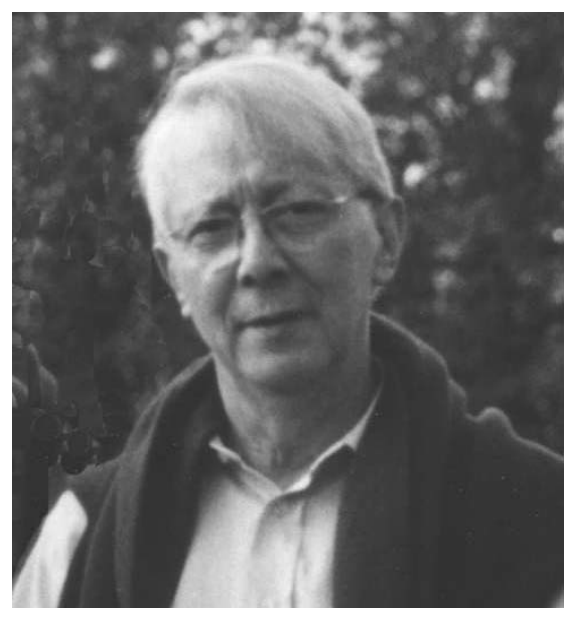

the quantitative histo- and cytochemistry. In particular, we will forever remember the way he communicated us his honest vision of science and life. Most importantly, however, we will miss a very good friend, always capable to avoid any arrogant or cheeky attitude in treating young colleagues, being instead always trustful with the new people coming in his laboratory and letting them to share the warmth of his family, with his beloved wife, Wieke, and their sons Marius, Jan, Bart and Lutze.

Ennio Prosperi and Carlo Alberto Redi 